\title{
HODNOTOVÝ REŤAZEC A STRATÉGIA DIFERENCIÁCIE V POŠTOVOM PODNIKU
}

\author{
Tatiana Čorejová - Lívia Gočalová ${ }^{1}$
}

\section{Úvod}

Základnou úlohou analýzy hodnotového ret’azca je nájdenie konkurenčnej výhody a ciest jej zvýšenia. Konkurenčná výhoda je nevyhnutným predpokladom pre dosiahnutie nadpriemerného výkonu v rámci určitého odvetvia (Porter, 1992). Aj ked' môže mat' podnik v porovnaní s konkurenciou nespočetné množstvo silných a slabých stránok, existujú dva základné typy konkurenčnej výhody, ktorú môže podnik mat'; nízke náklady alebo diferenciáciu. Význam ktorejkol’vek silnej alebo slabej stránky podniku je funkciou jej dopadu na náklady alebo diferenciáciu.

Tieto dva základné typy konkurenčnej výhody spolu s rozsahom činností, pre ktoré sa ich podnik snaží získat', vedú k trom základným stratégiám - stratégii nákladového vodcu, stratégii diferenciácie a stratégii fokusu s dvoma variantmi - sústredenie pozornosti na náklady a na diferenciáciu. Každá z týchto stratégií znamená odlišnú cestu ku konkurenčnej výhode. Stratégie vodcovského postavenia v nákladoch a diferenciácie hl'adajú konkurenčnú výhodu v širokom rade segmentov odvetví, zatial' čo fokálne stratégie sústred'ujú pozornost' na výhodu nízkych nákladov alebo na diferenciáciu v niektorom úzkom segmente.

Úzky rozsah môže vytvorit' konkurenčnú výhodu tým, že jej prispôsobí hodnotový ret’azec presne na mieru a širší rozsah zase využitím vzájomných vzt’ahov medzi hodnotovými ret’azcami, ktoré slúžia rôznym segmentom, odvetviam alebo geografickým oblastiam.

\section{Konkurenčná výhoda $v$ poštovom podniku}

Každá zo stratégií predstavuje zásadne rozdielny prístup k vytvoreniu a udržaniu určitej konkurenčnej výhody. Podstata stratégie nákladového vodcovstva je zrejmá už z jej názvu; podnik sa snaží o produkciu s výrazne nižšími nákladmi ako jeho konkurenti. Pri stratégii diferenciácie sa podnik snaží stat' sa jedinečným vo svojom odvetví a fokálna stratégia spočíva vo výbere úzkeho segmentu v rámci daného odvetvia, pre ktorý uplatňuje vybranú stratégiu.

Podnik si musí zvyčajne zvolit' jednu z uvedených stratégií, pretože dosiahnut' zároveň najnižšie náklady i diferenciáciu je - vzhl'adom na nákladnost' diferenciácie - spravidla nezlučitel'né. Avšak práve poštové podniky patria $\mathrm{k}$ podnikom, u ktorých je kombinácia týchto stratégií opodstatnená. Svojím diverzifikovaným portfóliom produktov v rámci uskutočňovaných činností napíňajú stratégiu diferenciácie, pričom však objem a počet

\footnotetext{
${ }^{1}$ Tatiana Čorejová, prof. Ing. PhD., Lívia Gočalová, Ing., University of Žilina, Faculty of Operation and Economics of Transport and Communications, Department of Communications, Univerzitna 1, 01026 Žilina, Slovak Republic, e-mail: tatiana.corejova@fpedas.utc.sk
} 
poskytovaných služieb predovšetkým v oblasti premiestňovacej i obstarávatel'skej činnosti umožňuje dosahovat' úspory z rozsahu i zo sortimentu, a teda nižšie náklady. Možnost' využívania kombinácie stratégií v prípade poštového podniku je odôvodnená tým, že o jej postavení z hl'adiska nákladov rozhoduje do značnej miery podiel na trhu viac ako ostatné faktory. Podiel na trhu je dôsledkom predchádzajúceho vývoja v odvetví, pričom však postupne dochádza k vzniku d’alších subjektov na trhu v súvislosti s procesmi liberalizácie. Výhody nízkych nákladov v niektorých činnostiach dovol’ujú rozhodujúcim poštovým podnikom vynaložit' zvýšené náklady inde, a tak znížit' náklady na diferenciáciu v pomere ku konkurentom. Ďalším dôvodom je to, že ostatné subjekty pôsobiace na trhu poštových služieb nevyužívajú v takom rozsahu existenciu vzájomných vzt'ahov medzi odvetviami a uplatňujú stratégie diferenciácie a fokusu vo vybraných produktoch a činnostiach.

Otázkou je udržatel'nost' jednotlivých stratégií v budúcnosti. V súčasnosti bývalé monopolné subjekty v pošte sú bezpochyby vodcami na trhu poštových služieb. Ked' ale zvážime všetky okolnosti tohto postavenia a blížiacu sa úplnú liberalizáciu poštového trhu, práve ich trhový podiel a výnosnost' môžu byt' atraktívne pre podniky, ktoré majú v pláne do tohto odvetvia vstúpit' alebo si v ňom zlepšit' postavenie. Postupujúca liberalizácia poštového trhu môže uvol'nit' cenovú konkurenciu a základom nízkej ceny sú nízke náklady. Logika stratégie vodcovského postavenia v nízkych nákladoch však vyžaduje, aby bol daný podnik skutočne podnikom s najnižšími nákladmi, nielen jedným z niekol'kých podnikov, ktoré o toto postavenie súperia.

Poštový podnik sa nemôže jednoznačne rozhodnút' pre určitú stratégiu bez toho, aby skúmal ich možnosti a nástrahy. Prostriedkom pre nájdenie konkurenčnej výhody a ciest jej zvýšenia sa môže stat' hodnotový ret'azec. Jeho analýzou z hl'adiska základných stratégií, ich modifikácie vzhl'adom na ciel’ový segment a zohl'adnení scenárov budúceho vývoja je možné rozhodnút' sa pre jednu zo stratégií alebo odôvodnit' používanie ich kombinácií. Hodnotový ret’azec je nástrojom, ako môže poštový podnik získat' jasnú predstavu o jednotlivých segmentoch zákazníkov, ich potrebách a stratégii uspokojovania týchto potrieb.

Účelom uplatnenia hodnotovej analýzy a skúmania hodnotového ret’azca je určenie súboru zmysluplných rozdielov, ktorými podnik odlíši svoju ponuku od ponúk konkurenčných podnikov. Diferenciácia môže pramenit' zo špecifických činností, ktoré realizuje podnik a z toho, ako tieto činnosti pôsobia na zákazníka. Potenciálnym zdrojom jedinečnosti je prakticky akákol'vek hodnototvorná činnost'.

\section{Analýza hodnotových ret’azcov zákazníkov}

Podnik vytvára pre zákazníka určitú hodnotu. Aby mohol pochopit', čo zákazník pokladá za hodnotné, musí analyzovat' jeho hodnotový ret’azec. Ten zostaví na základe všeobecného modelu hodnotového ret’azca, pričom všetky aktivity hodnotového ret'azca zákazníka sa analyzujú vzhl'adom na existujúce alebo potenciálne väzby s činnost’ami vlastného hodnotového ret’azca (Klien, 1995).

Vzhl'adom na početnost' zákazníkov poštového podniku nie je možné analyzovat' hodnotové ret’azce zákazníkov jednotlivo, ale používajú sa postupy vychádzajúce zo segmentácie zákazníkov, a to minimálne na 2 segmenty: obchodní zákazníci - podniky a súkromní zákazníci - domácnosti.

Spôsob vstupu poštového podniku do hodnotových ret'azcov svojich zákazníkov je znázornený na obr. 1, a to na príklade zásielok 2. triedy. 


\begin{tabular}{|c|c|c|c|c|}
\hline \multicolumn{5}{|c|}{$\begin{array}{c}\text { INFRAŠTRUKTÚRA PODNIKU } \\
\text { - potreby riadenia (komunikácia s partnermi, vlastníkmi, finančnými } \\
\text { inštitúciami), účtovníctva (účtovné doklady), administratívne činnosti, } \\
\text { právne dokumenty a i. }\end{array}$} \\
\hline \multicolumn{5}{|c|}{$\begin{array}{l}\text { RIADENIE L'UDSKÝCH ZDROJOV } \\
\text { - komunikácia so súčasnými i potenciálnymi zamestnancami, s verejnými } \\
\text { inštitúciami a p. }\end{array}$} \\
\hline \multicolumn{5}{|c|}{$\begin{array}{c}\text { TECHNOLOGICKÝ ROZVOJ } \\
\text { - komunikácia s dodávatel'mi IKT a iných zariadení, vývojármi, výskumnými } \\
\text { alianciami, obeh dokumentov }\end{array}$} \\
\hline \multicolumn{5}{|c|}{$\begin{array}{c}\text { OBSTARÁVANIE } \\
\text { - komunikácia s dodávatel'mi - súčasnými i potenciálnymi } \\
\end{array}$} \\
\hline $\begin{array}{l}\text { MARKETING } \\
\text { A ODBYT } \\
\text { - komunikácia } \\
\text { so zákazníkmi, } \\
\text { - fyzická } \\
\text { distribúcia } \\
\text { tovaru zák. }\end{array}$ & $\begin{array}{c}\text { VSTUPNÁ } \\
\text { LOGISTIKA } \\
\text { - prijímanie } \\
\text { krátkodobého } \\
\text { majetku, vrát. } \\
\text { tovaru } \\
\text { dodávatel'om }\end{array}$ & $\begin{array}{l}\text { OPERAČNÁ } \\
\text { ČINNOST̃ } \\
\text { - spracovanie } \\
\text { zásielok }\end{array}$ & $\begin{array}{l}\text { VÝSTUPNÁ } \\
\text { LOGISTIKA } \\
\text { - objednáv- } \\
\text { kový systém }\end{array}$ & $\begin{array}{l}\text { poradenstvo } \\
\text { st’ažnosti } \\
\text { rekla- } \\
\text { ácie }\end{array}$ \\
\hline
\end{tabular}

Obr. 1 Hodnotový ret’azec obchodného zákazníka poštového podniku

Jednotlivé činnosti majú v podstate dvojaký charakter - na jednej strane podnik vystupuje ako odosielatel' a na druhej ako príjemca. Spoznat' hodnotový ret'azec podnikov je vzhl'adom na ich podobnost' s ret'azcom podniku intuitívne l'ahké. Je však náročnejšie zostavit' hodnotový ret'azec, ktorý by obsahoval všetko, čo robí domácnost' a jej členovia, hoci logika analýzy zostáva rovnaká aj v tomto prípade. Preto je možné zostavit’ ret’azec len pre tie činnosti, ktoré sú rozhodujúce pre spôsob určitého používania služby. Ret'azce nemusia byt' zostavované pre každú domácnost', ale pre reprezentatívnu domácnost' (Porter, 1992).

Aj ked' boli zákazníci rozdelení do dvoch skupín, produkt v podstate nekupuje podnik alebo domácnost', ale jednotlivci, ktorí o použití rozhodujú. Relevantnými zákazníkmi, ktorých treba skúmat', sú nielen títo jednotlivci, ale aj osoby, ktoré ich ovplyvňujú (Klien, 1995). Podl’a Portera každý podnik vytvára hodnotu pre zákazníka dvoma spôsobmi:

- znížením jeho nákladov,

- zvýšením jeho výkonnosti.

Pri hladaní príležitostí na zníženie nákladov zákazníka musí podnik podrobne zmapovat', ako jeho produkty prechádzajú hodnotovým ret’azcom zákazníka, alebo ako ich ovplyvňuje. U obchodných zákazníkov diferenciácia vyžaduje, aby bola pošta schopná vytvorit' svojim zákazníkom konkurenčnú výhodu nielen tým, že im poskytne produkty za nižšie poštové sadzby, ale ešte d'alšími spôsobmi (napr. zberné jazdy či prenájom výplatných strojov). To platí aj pre domácnosti a individuálneho zákazníka, i ked' meranie nákladov a výkonnosti bude problematickejšie. U domácnosti zahŕňajú náklady na poskytnuté služby nielen finančné náklady, ale i náklady na čas - tie odrážajú náklady alternatívnej príležitosti strávit' ho inde a zároveň implicitné náklady frustrácie alebo námahy. Hodnota pre zákazníka vyplýva z toho, že mu znižuje ktorýkol'vek z týchto nákladov. Typickým príkladom je bežné podávanie listových zásielok 2. triedy priamo na poštách, kde stratu času spôsobujú čakacie doby pri priehradkách, ale aj d’alšie časy vynaložené zo strany zákazníka - odchod z pracoviska a príchod na poštu.. V tejto súvislosti môže zákazník znížit' svoje náklady aj tým, že bude využivat' služby toho istého poštového operátora, ale s iným spôsobom podania, 
pričom pošta pri každom z nich môže prispiet' vytváraním vhodných podmienok ich využívania (napr. pre účely podania pomocou poštovej schránky dôslednou distribúciou poštových známok).

Ak ciel’om obchodných zákazníkov nie je len zisk alebo rast príjmov, na zvyšovanie ich výkonnosti slúži tiež prestíž, ktorú im je poštový podnik schopný ponúknut'. U individuálneho zákazníka zvýšit' výkonnost' znamená zvýšit' úroveň jeho uspokojenia. Nejde tu pritom len o základné požiadavku včasnosti doručenia zásielok, ale aj o možnost' uspokojit' vyššie nároky pomocou doplnkových služieb. Za vyšší stupeň uspokojenia si bude zákazník samozrejme ochotný zaplatit’ i cenovú prirážku.

\section{Posúdenie udržatel'nosti diferenciácie}

Uspokojovanie diferencovaných potrieb zákazníkov je síce základným predpokladom výnosnosti, ale samo o sebe nestačí. Závažnou otázkou pri určovaní výnosnosti je, či si poštový podnik dokáže hodnotu vytvorenú pre zákazníka uchovat' úplne, alebo či sa táto hodnota dostane v konkurenčnom boji do iných rúk. Dlhodobá udržatel'nost' diferenciácie závisí od toho, že:

- si zákazníci budú hodnotu pre nich vytvorenú neustále uvedomovat',

- konkurenti túto hodnotu nenapodobňujú.

Neustále existuje možnost', že potreby alebo predstavy zákazníkov sa zmenia. V tejto súvislosti sa do popredia dostáva otázka, do akej miery musí podnik v budúcnosti počítat' so zmenou požiadaviek zákazníkov. Napríklad v podmienkach Slovenskej pošty, a.s. sa očakáva medziročný pokles podaní listových zásielok 2. triedy asi o tri percentá (Tolnayová, 2005). Komunikačné technológie (napr. využívanie e-mailu) predstavujú pre poštu konkurenciu, ale súčasne aj príležitost' reagovat' na nové požiadavky zákazníkov. Príkladom môže byt' hybridná pošta, ktorá je spojením tradičnej a elektronickej pošty. V tejto súvislosti je ešte nutné podotknút', že zmenou techniky riešenia pôvodného zákazníckeho problému sa tento môže od základu zmenit'. Zmenou riešitel'skej techniky podmienenej inováciami sa menia nákupné kritériá, posúva sa hodnotová relevancia určitých aktivít a tiež význam hnacích síl jedinečnosti (Klien, 1995).

Diferenciácia môže byt' dlhodobejšie udržatel'ná za týchto podmienok:

1. Zdroje jedinečnosti podniku, ktoré vyplývajú najmä zo znalostí a skúseností, obsahujú i prekážky pre konkurentov. Diferenciácia založená príliš na signalizovaní hodnoty je však stále zranitel'nejšia zo strany rastúcej náročnosti zákazníkov.

2. Podnik má pri diferenciácii výhodu nízkych nákladov.

3. Zdrojov diferenciácie je viac. Konkurenti môžu diferenciačnú stratégiu napodobnit’ o to t’ažšie, čím viac zdrojov diferenciácie podnik má. Poštový podnik, z hl'adiska všetkých poskytovaných činností, práve v dôsledku počtu vykonávaných činností a poskytovaných služieb má potenciál uplatnit' diferenciáciu, ktorá je z hl'adiska konkurencie vel'mi t'ažko napodobitel'ná (Porter, 1992).

\section{Záver}

Zostavenie hodnotového ret'azca je determinované rozsahom činností, ktoré poštový podnik realizuje. V nadväznosti na možnosti uplatnenia stratégie diferenciácie je nutné d'alej hl'adat' faktory, ktoré podstatne vplývajú na hodnotový ret’azec, či už z hl'adiska technológie, geografického rozsahu, segmentácie trhu alebo možností integračných a diverzifikačných stratégií.

Podobným spôsobom je možné pristupovat' aj pri uplatnení stratégie nákladového vodcovstva, ktorá je spojená s analýzou možností znižovania nákladov. Ako už bolo uvedené, tieto dve stratégie sa v prípade poštového podniku nemusia nevyhnutne vylučovat'. Poštový 
podnik musí využit' každú príležitost' znížit' náklady, nevedúce $\mathrm{k}$ strate diferenciácie a tiež každú príležitost' $\mathrm{k}$ diferenciácii, ktorá nie je nákladná.

\section{Literatúra}

DOSTÁL, V. 2003. Analýza funkcí a funkční analýza v pojetí hodnotového managementu aneb co v EN není a co se nám v nich nelíbí. In: Prosperita firmy vyžaduje růst hodnoty pro zákazníka [Sborník Českého komitétu pro vědecké řízení]. [online]. [Cit. 2005-0117]. Dostupné na: <http://www.ccsm.cz/ OA403iDostal.doc>

KLIEN, W.: Wertsteigerungsanalyse und Messung von Managementdienstleistungen: Technik, Logik und Anwendung. DUV, Dt. Univ.-Verl., 1995. ISBN 3-8244-0236-X

MEFFERT, H.: Marketing-Management: Analyse, Strategie, Implementierung Wiesbaden, 1994. Podl'a: Hils, M. 2000. Beschaffung und Vertrieb von Dienstleistungen. [Seminárna práca]. [online]. Posledná aktualizácia 10. apríl 2000. http://www.hausarbeiten.de/faecher/hausarbeit/bwu/ 7224.html>

MEFFERT, H. - SCHNEIDER, H. 2004. Vorlesung Dienstleistungmarketing Wintersemester 2004, 2005 Posledná aktualizácia 17. november 2004. <http://www.marketingcentrum.de/ifm/lehre/lehre-files/2005-0118\%20folien_12_sitzung.pdf>

MOLNÁR, P. 2003. Súčasné trendy v metodológii hodnotového manažmentu a jeho aplikácie vo vyspelom zahraničí. In: Prosperita firmy vyžaduje růst hodnoty pro zákazníka [Sborník Českého komitétu pro vědecké řízení]. [online]. $<$ http://www.ccsm.cz/OA403iMolnar.doc $>$

MÜLLER-STEWENS, G. - LECHNER, Ch.: Strategisches Management. Wie strategische Initiativen zum Wandel führen Schäffer-Poeschel: Stuttgart, 2001. Podl'a: Scheuchner, R.: Strategische Wertkettenanalyse. [online]. http://www.mainland.at/kompetenz/publikationen/files/strategischewertkettenanalyse_0 803.pdf>

PORTER, M. E.: Konkureční výhoda (Jak vytvořit a udržte si nadprůměrný výkon). Victoria Publishing, Praha, 1992. ISBN 80-85605-12-0

PRAŽSKÁ, L. - JINDRA, J. a kol.: Obchodní podnikání. Management Press, Praha, 1997. ISBN 80-85943-48-4

ROSTÁŠOVÁ, M.- KREMEŇOVÁ, I.: Marketing v službách. Algoritmy marketingových činností. EDIS, Žilinská univerzita v Žiline, Žilina, 2005, ISBN 80-8070-355-8

SCHEUCHNER, R. Strategische Wertkettenanalyse [online]. [Cit. 2005-11-25]. $<\mathrm{http}$ //www.mainland.at/kompetenz/publikationen/files/strategischewertkettenanalyse_ 0803.pdf>

STOPKA, U.: Prednášky z predmetu Manažment v službách. Technická univerzita Drážd’any, Drážd’any, 2003.

TOLNAYOVÁ, M.: Informatizácia prinesie pošte nové možnosti. In: Hospodárske noviny, roč. XIII., 25.jan.2005, č. 16, s. 13. ISSN 1335-4701

VEBER, J.: Management: Základy, prosperita, globalizace. Management Press, Praha, 2000. ISBN 80-7261-029-5

VLČEK, R.: Hodnota pro zákazníka. Management Press, Praha, 2002. ISBN 80-7261-068-6

VLČEK, R.: Hodnotový management. Management Press, Praha, 1992. ISBN 80-85603-09-8 